\title{
新しい創薬資源としての变形菌に関する研究
}

\author{
石 橋 正已
}

\section{Study on Myxomycetes as a New Source of Bioactive Natural Products}

\author{
Masami ISHIBASHI \\ Graduate School of Pharmaceutical Sciences, Chiba University, \\ 1-33 Yayoi-cho, Inage-ku, Chiba 263-8522, Japan
}

(Received May 17, 2007)

\begin{abstract}
The Myxomycetes (true slime molds) are an unusual group of primitive organisms that may be assigned to one of the lowest classes of eukaryotes. As their fruit bodies are very small and it is very difficult to collect much quantity, few studies have been made on the chemistry of myxomycetes. We studied spore germination experiments of hundreds of field-collected myxomycetes collected in Japan, and succeeded in laboratory culture of plasmodia of several myxomycetes in a practical scale for natural products chemistry studies. Pyrroloiminoquinones, polyene yellow pigments, and a peptide lactone were isolated from cultured plasmodia of myxomycetes, while new naphthoquinone pigments, cycloanthranilylprolines, tyrosine-kinase inhibitory bisindoles, a cytotoxic triterpenoid aldehyde lactone, a dibenzofuran glycoside, and sterols possessing an unprecedented 2,6-dioxabicyclo [2.2.2] octan-3-one ring system, were also isolated from field-collected fruit bodies of myxomycetes.
\end{abstract}

Key words_— natural products; myxomycetes; true slime molds

\section{1.はじめに}

変形菌は, 系統分類学的には最も下等な真核生物 の 1 つとして位置付けられ，その生活環のなかで, 胞子, アメーバ体, 変形体, 子実体など様々な形態 を取るユニークな生物である（Fig. 1)。日本では 南方熊楠が研究対象としたことで知られており，日 本の変形菌研究史には薬学分野から朝比奈泰彦, 落 合英二らも名を連ねている，変形菌を対象とした天 然物の探索に関しては Steglich ら, 1) 浅川ら2)による 報告が 1980-90 年代を中心に数例あつたものの，そ の後はあまり進展していなかった，以下，当研究室 において最近行った変形菌からの天然物探索に関す る研究の概要を報告する. ${ }^{3-6)}$

\section{2. 変形菌の培養と培養変形体の化学成分}

2-1. 変形菌の培養全国各地で 2002 年以降 に採取した変形菌の子実体 202 株, 菌核 9 株, 変形 体 11 株, 計 222 株について, 寒天平板培地上での

千葉大学大学院薬学研究院（干263-8522 千葉市稲毛区 弥生町 1-33)

e-mail: mish@p.chiba-u.ac.jp

本総説は, 平成 19 年度日本薬学会学術振興賞の受賞を 記念して記述したものである。
胞子の発芽実験を行った。実験手順は以下の通りで ある。

1）野外変形菌子実体（Fig. 2）に含まれる胞子 を，大腸菌共存下，寒天平板培地に塗布する。

2）胞子が発芽すると，大腸菌中に溶菌斑（粘菌 アメーバ）が観察される.

3）溶菌斑中の粘菌アメーバを繰り返し新しい平 板培地に接種し，混在菌を除去する。

4）新しい平板培地への接種を繰り返すうち，粘 菌アメーバから変形体の形成がみられる。変形体

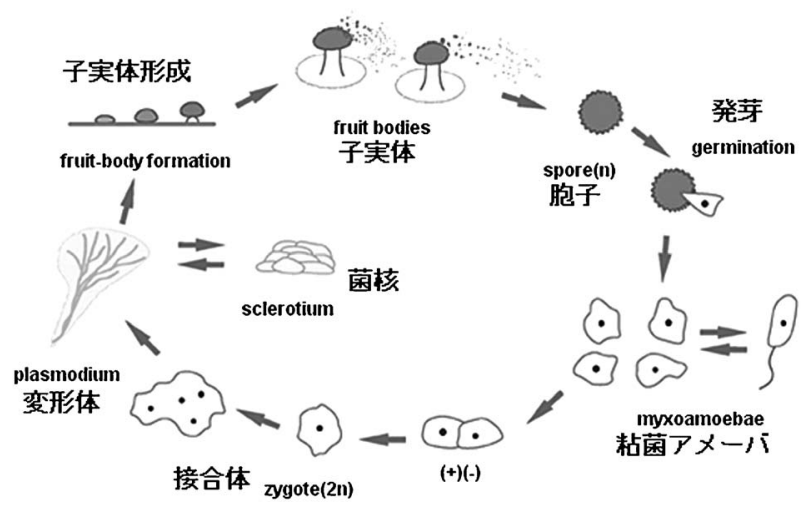

Fig. 1. Lifecycle of Myxomycetes 


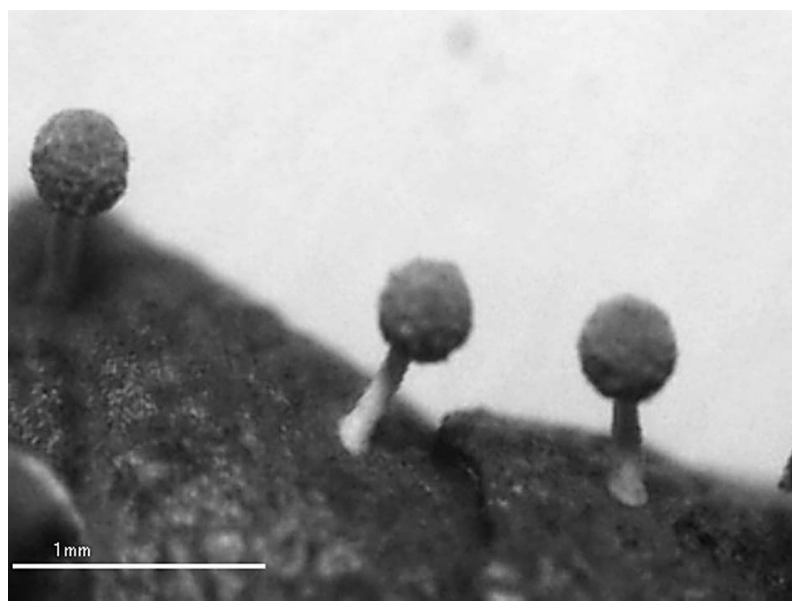

Fig. 2. Wild Fruit-body (Physarum melleum)

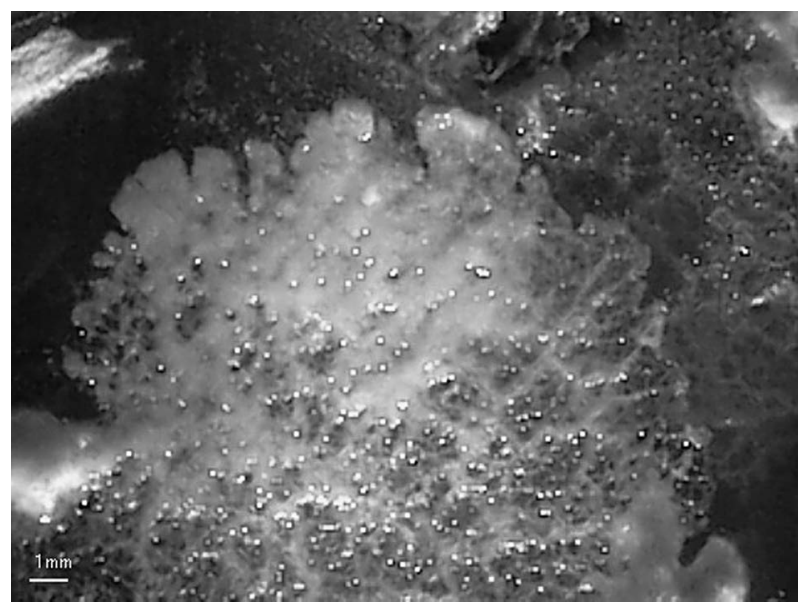

Fig. 3. Cultured Plasmodium (Physarum melleum)

（Fig. 3）は, 大腸菌非存在下, オートミールを餌 として加えると成長する.

5）変形体が成長すると，適切な条件下において 平板培地上で子実体（Fig. 4）を形成する．変形体 の安定培養が可能となつた菌株について, 寒天培地 上での大量培養を行い, 収穫した変形体を抽出し, 化学成分を探索する.

上記のような方法で実験を行った結果，222 株の うち，80 株 $(37 \%)$ で発芽， 45 株 $(21 \%)$ で変形 体形成，9株（4\%）で子実体形成に成功した（Fig. 5 及び Table 1)。培地としては主に, LP 培地及び Agar 培地を使用した（Table 1). 本実験条件下で は, Didymiaceae 科, Physaraceae 科は発芽し易 く, 変形体・子実体もほかの属に比べて形成し易い ことが明らかとなった。この 2 科以外では, 唯一 Arcyriaceae 科の 1 株（Arcyria cinerea）で子実体

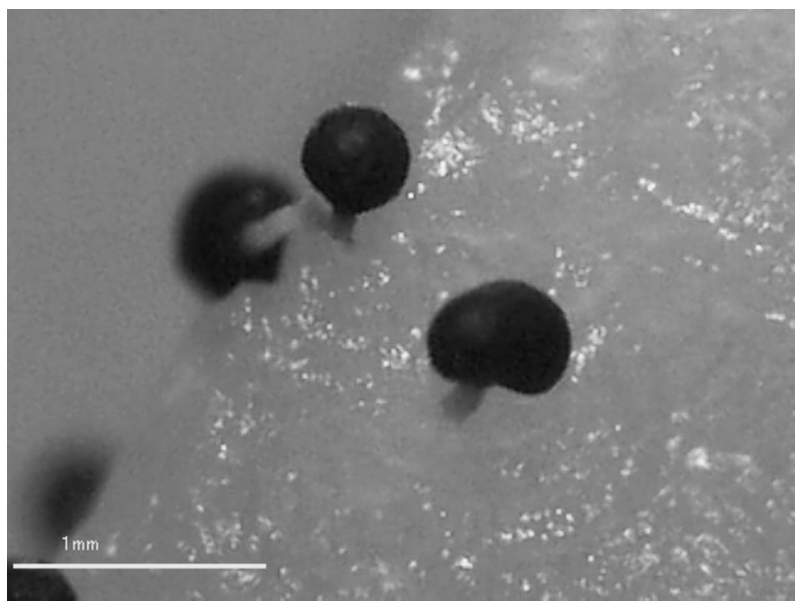

Fig. 4. Cultured Ffruit-body (Physarum melleum)

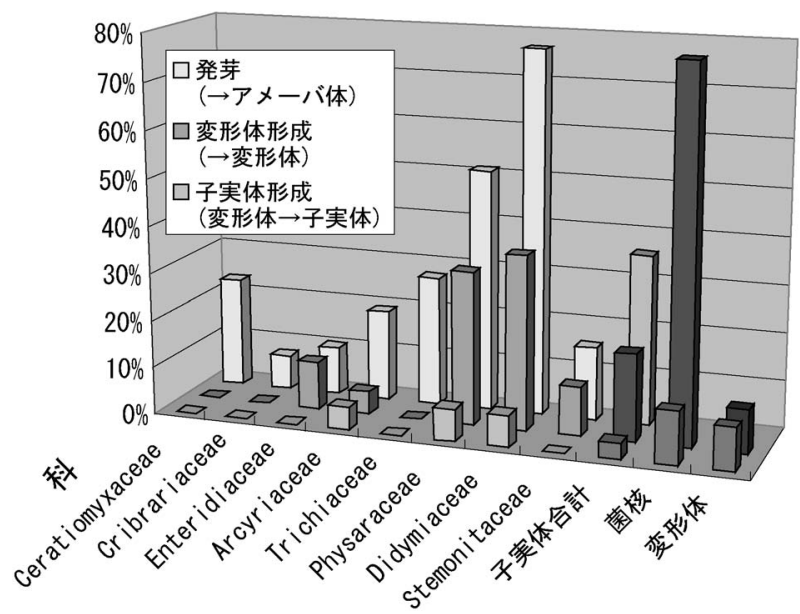

Fig. 5. Relationship between Spore-germination Ratio and Species

形成に成功した（Fig. 6 及び Fig. 7)。このような 結果から, 現在の培養条件に適している種と適して いない種があることが分かった．変形菌は野外にお いて倒木あるいは枯葉上に生息していることが多い が，本実験で発芽が観測されたのは枯葉上に生息し ていた種が多いという傾向がみられた。 寒天平板培 地上で子実体を形成した株の多くは，培養して得ら

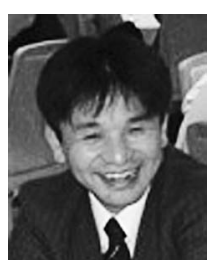

石橋正己
千葉大学大学院薬学研究院教授 (活性 構造化学研究室). 1957 年佐賀県生ま れ. 1985 年東京大学大学院理学系研究 科化学専攻博士課程修了. 八ワイ大 学, 三菱化成生命科学研究所, 北里研 究所博士研究員, 東邦大学講師を経て, 1990 年北海道大学薬学部助教授 (生薬 学講座), 1997 年より千葉大学教授. 専門 : 天然物化学. 
Table 1. Relationship between Spore-germination Ratio and Species ${ }^{a}$

\begin{tabular}{|c|c|c|c|c|c|c|c|c|c|}
\hline & & 科 & 株数 & & 芽 & & 形成 & & 彤成 \\
\hline \multirow{9}{*}{ 胞 子 } & Ceratiomyxales & Ceratiomyxaceae & 13 & 3 & $23 \%$ & 0 & $0 \%$ & 0 & $0 \%$ \\
\hline & \multirow{2}{*}{ Liceales } & Cribrariaceae & 14 & 1 & $7 \%$ & 0 & $0 \%$ & 0 & $0 \%$ \\
\hline & & Enteridiaceae & 10 & 1 & $10 \%$ & 1 & $10 \%$ & 0 & $0 \%$ \\
\hline & \multirow{2}{*}{ Trichiales } & Arcyriaceae & 21 & 4 & $19 \%$ & 1 & $5 \%$ & 1 & $5 \%$ \\
\hline & & Trichiaceae & 11 & 3 & $27 \%$ & 0 & $0 \%$ & 0 & $0 \%$ \\
\hline & \multirow{2}{*}{ Physarales } & Physaraceae & 59 & 30 & $51 \%$ & 19 & $32 \%$ & 4 & $7 \%$ \\
\hline & & Didymiaceae & 30 & 23 & $77 \%$ & 11 & $37 \%$ & 2 & $7 \%$ \\
\hline & Stemonitales & Stemonitaceae & 39 & 6 & $15 \%$ & 4 & $10 \%$ & 0 & $0 \%$ \\
\hline & \multicolumn{2}{|c|}{ 未同定 } & 5 & 1 & $20 \%$ & 1 & $20 \%$ & 0 & $0 \%$ \\
\hline 菌 核 & \multicolumn{2}{|c|}{ 未同定 } & 9 & & & 7 & $78 \%$ & 1 & $1 \%$ \\
\hline 変形体 & \multicolumn{2}{|c|}{ 未同定 } & 11 & & & 1 & $9 \%$ & 1 & $9 \%$ \\
\hline \multicolumn{3}{|c|}{ 合計（子実体＋菌核＋変形体） } & 222 & 80 & $37 \%$ & 45 & $21 \%$ & 9 & $4 \%$ \\
\hline
\end{tabular}

a) Culture medium. (1) "LP": Lactose 0.1\%, Peptone 0.1\%, $\mathrm{KH}_{2} \mathrm{PO}_{4} 0.205 \%, \mathrm{Na}_{2} \mathrm{HPO}_{4} \cdot 12 \mathrm{H}_{2} \mathrm{O} 0.083 \%$, Agar $1.5 \%$. (2) “Agar” : Agar $1.5 \%$.

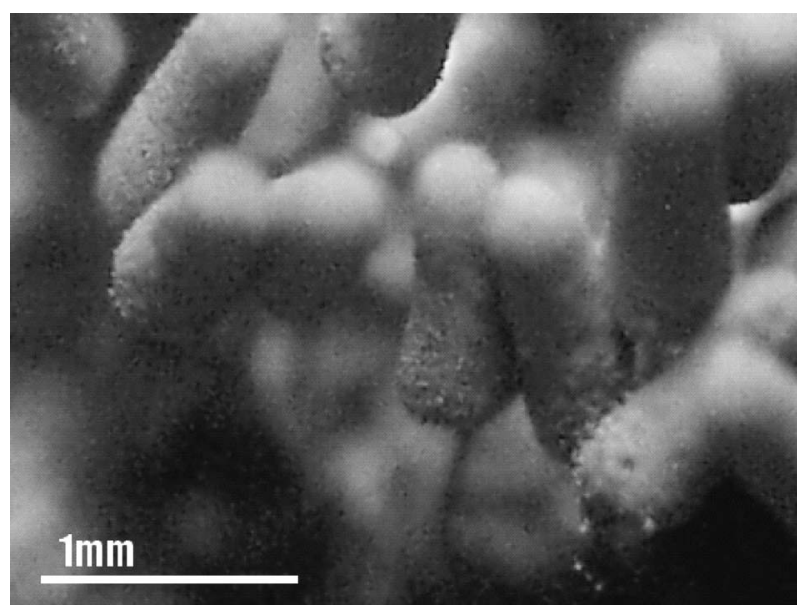

Fig. 6. Wild Fruit-body (Arcyria cinerea)

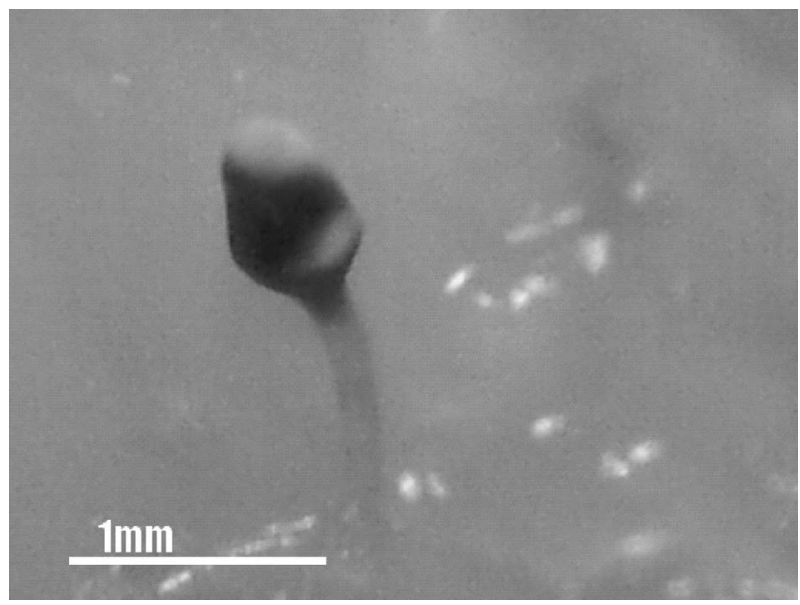

Fig. 7. Cultured Fruit-body (Arcyria cinerea)
れた胞子を再度大腸菌を塗布した平板培地上に接種 したところ胞子の発芽が観察された。 すなわち，こ れらの菌株については胞子から胞子への実験室内で の生活環の一巡に成功した．また得られた胞子はス キムミルクーグルコース液に懸濁させることにより 凍結保存が可能である.

2-2. 培養変形体の成分 変形体培養が可能と なったもののうち, 平板培地上で安定して変形体の 成長が観察された数種の菌株について大量培養を行 い，変形体の成分研究を行つた.

2-2-1. Didymium bahiense (バイアカタホコリ) 本菌（長野県小黒川産）についてオートミールを添 加した平板プレート $(\varphi 9 \mathrm{~cm})$ を用いた大量培養を 行い, プレート 793 枚から凍結乾燥菌体 $84.3 \mathrm{~g}$ を 得た。本菌体より褐色色素であるピロロイミノキノ ン型インドールアルカロイド makaluvamine A (1) を分離した.7) 1 は，以前海綿 Zyzzya cf. marsailis8) よりトポイソメラーゼ阻害物質として分離されてい たが，陸棲生物から分離されたことは初めてであっ た. また, 本菌培養変形体抽出物の脂溶性画分から は新規グリセ口脂質成分 bahiensol (2) を単離し た. ${ }^{9)}$ 本菌は培養子実体形成にも成功したため, 培 養子実体抽出エキスを作成し，TLC 分析を行った が，培養子実体中には makaluvamine A（1）の存 在は認められなかった。 
2-2-2. Didymium iridis（ゴマシオカタホコリ） 本菌（福井県越知山産）の変形体をオートミールを 加えた寒天培地上, プレート 114 枚分の大量培養を 行った．得られた変形体の抽出物より 2 種のピロロ イミノキノン型インドールアルカロイド makaluva-

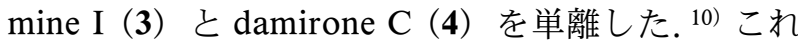
らはともに以前海綿 Zyzzya fuliginosa11) から単離 された化合物であり，今回初めて変形菌より単離さ れた。海綿は体内にバクテリアや微細藻などを共生 （共存）させていると言われるので，本成分の真の 生産者は海綿自身ではない可能性が考えられる，ま た，海綿の飼育は一般に容易ではないが，Didymium bahiense の変形体は，平板培地上ではあるが, 繰り返し培養して増やすことができる.

\section{2-2-3. Physarum rigidum（イタモジホコリ）} 本菌（埼玉県所沢市産）は，発芽実験により黄色の 変形体を形成し，さらに光照射により子実体形成に
も成功した．本菌の変形体はオートミールを加えた 寒天培地に植菌後, 約 1 週間で $\varphi 9 \mathrm{~cm}$ シャーレ 1 面に広がる。プレート 1050 枚分の大量培養を行 い，得られた変形体の抽出物について TLC 分析を 行ったところ，極めて多くの黄色色素成分が複雑な 混合物として含まれていることが判明した。これら は高極性で有機溶媒に難溶であり，かつ比較的不安 定であったが，クロマトグラフィーによる精製を注 意深く行うことにより 3 種の黄色色素成分 physaridin $\mathrm{A}-\mathrm{C} （ 5-7)$ を単離した。これらは，2-メト キシフェニルアセトアミドにヘキサエン又はペンタ エンを含む側鎖が結合し，その側鎖の末端にはさら に $\beta$-アミノ酸がアミド結合した新規化合物であつ た. ${ }^{12)}$

2-2-4. Physarum melleum (シロジクキモジホコ リ）本菌株（埼玉県所沢市産）の変形体を，大 腸菌を塗布した平板培地上で， $25^{\circ} \mathrm{C}$, 暗所で約 1 週<smiles></smiles>

1<smiles>CCCCC(C)C(C)(O)C(C)CCCC(O)CCOCC(O)CO</smiles>

2

$m+n=7$<smiles>NC1=CC2=NCCc3c[nH]c(c32)C1=O</smiles>

3<smiles>O=C1C=C2NCCc3c[nH]c(c32)C1=O</smiles>

4<smiles>COc1cccc(/C=C/C=C/C=C/C=C/C=C/C=C/C(=O)NCCC(=O)O)c1NC(C)(C)C</smiles>

5<smiles>COc1cccc(/C=C/C=C/C=C/C=C/C=C/C=C/C(=O)NCC(C)C(=O)O)c1NC(C)(C)C</smiles>

6<smiles>COc1cccc(/C=C/C=C/C=C/C=C/C=C/C(O)CC(=O)NCCC(=O)O)c1NC(C)(C)C</smiles> 
<smiles>COc1ccc(C(=O)N[C@H](C(=O)NCC(=O)N[C@@H](Cc2ccc(O)cc2)[C@@H](O)CC(=O)O)[C@H](C)O)cc1</smiles>

8<smiles>COC(=O)C[C@H](O)[C@H](Cc1ccc(O)cc1)NC(=O)CNC(=O)[C@H](NC(=O)c1ccc(OC)cc1)C(C)O</smiles>

9
間培養した。本菌抽出物には, Physarum rigidum 亡同様に，多くの黄色色素成分が含まれており，ま た，その黄色色素成分は枯草菌 (Bacillus subtilis) に対する抗菌活性を有していることも示唆された. しかしながら，本黄色色素は多成分かつ不安定，溶 媒難溶性等の性質を持っていたため分離が難航し, 残念ながら, 抗菌活性本体である本色素成分の解明 には現在のところ至っていない. 一方, 本抽出エキ スの脂溶性画分にはUV 吸収を示す特徵的成分が含 まれることが TLC 分析により判明した。 そこで, プレート約 3000 枚分の大量培養を行い, 変形体抽 出物の脂溶性画分の分離精製を行うことにより，新 規化合物 melleumin A（8）及びB（9）を単離した。 Melleumin A（8）は，スペクトルデータの解析に より, $p$-メトキシ安息香酸，スレオニン，グリシ ン残基，及びチロシンが結合した酢酸ユニットから 構成されるトリペプチドラクトン構造を持つことが

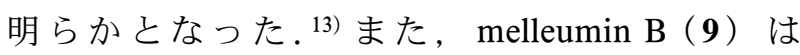
melleumin A（8）のセコ酸メチルエステル構造を有 していた.これらの立体化学に関しては，まずスレ オニン残基の 10,11 位の絶対立体配置を決定する ため, 9 を用いて酸加水分解を行い, キラル TLC 及び ODS TLC 分析により，4 種類のスレオニン異 性体標品（10S1 $1 S, 10 S 11 R, 10 R 11 R, 10 R 11 S ）$ との 比較を行った。 その結果, $\mathrm{R}_{\mathrm{f}}$ 值から 9 に含まれる スレオニンは L- スレオニンであることが明らかと なり, 絶対立体配置を $10 S, 11 R$ と決定した. 一方, 3 位の絶対立体配置については，9の $(R)$ 及び $(S)$ MTPA エステル化を行い, Kusumi-Mosher 法を適 用することにより， $3 S$ 配置であることを明らかに した。また， $\mathrm{NaOMe}$ を用いて 8 の開環反応を行う ことにより，9が生成されることが TLC 分析の結 果から示唆されたことから， 1 及び 2 の立体配置は 同一であることが示唆された。残された 4 位の絶対 立体配置については，L-チロシンと酢酸エチルと
の縮合により，4 位に関する 2 つのジステレオ マーを調製し，HPLC 分析を行うことにより $4 S$ 配 置であると決定した，現在，melleumin A（8）の全 合成研究を行っており，さらには melleumin A (8) をモチーフとした合成化合物ライブラリーの構築を 計画している. ${ }^{14)}$

2-3. 培養変形体の色の変化 上記の培養実験 を行っている過程で, 次のような興味深い現象が観 察された。 Didymium flexosum の変形体の培養に おいて，培養変形体の色は通常は白色（Fig. 8）で あつたが，シャーレ内に混在菌が共存していると紫 色（Fig. 9）になることがあつた。また，植え継ぎ を繰り返して混在菌をシャーレから除去すると，次 第に変形体の色は元の白色へと戻つた．混在菌から 身を守るため，あるいは混在菌を退治するために， 本菌の変形体は紫色物質を生産すると予想される. この紫色物質の解明には至っていないが，混在菌を 多すぎず少なすぎず，程よく混在させて培養すると いう培養条件をつかむことが必要となる。同じ現象 は, Diderma platycarpum var. berkeleyanum の変形 体の培養においても観察された。しかも本菌の場合 は，紫色のときの方が白色のときよりも変形体の成 長が速いと思われた。この紫色物質（Didymium flexosum の紫色物質と同じか否かは不明）は変形 体の成長促進作用も持つことが予想される。混在菌 に負けないためには速く成長する必要があり，理に かなっている.

\section{3. 野外子実体の化学成分}

一方, 上述の培養変形菌の成分研究と並行して, 野外採取により入手した変形菌子実体についての化 学成分の研究も行つた。 まず，野外採取子実体抽出 物に対して，枯草菌（Bacillus subtilis）に対する抗 菌活性試験, フローサイトメトリーを用いた培養ヒ 卜子宮頸癌（HeLa）細胞に対する細胞周期進行阻 害活性試験, 及び各種発色試薬に対する TLC 上の 


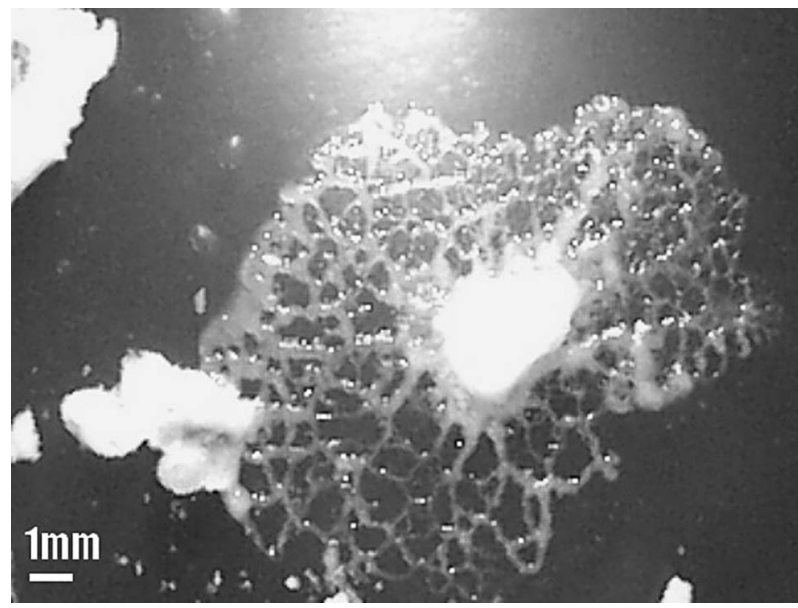

Fig. 8. Cultured Plasmodium (Didymium flexosum), White Color<smiles>COC1=CC(=O)c2c(O)c3c(c(O)c2C1=O)OCC3O</smiles>

10<smiles>[R20]Oc1cc2c(c(O)c1[R20])C(=O)C(/C=C/C(=O)CCC)C(O)C2=O</smiles>

$12 R_{1}=R_{2}=H$

$13 \mathrm{R}_{1}=\mathrm{H}, \mathrm{R}_{2}=\mathrm{CH}_{3}$

$14 \mathrm{R}_{1}=\mathrm{R}_{2}=\mathrm{CH}_{3}$

ケミカルスクリーニング試験を行った。その結果を Table 2 に示した。本スクリーニング結果に基づ き, 以下のような化学成分の探索を行った.

3-1. ナフトキノンＣribraria purpurea（ムラ サキアミホコリ）より枯草菌に対する抗菌活性を持 つ新規ナフトキノン型赤色色素 cribrarione A (10)

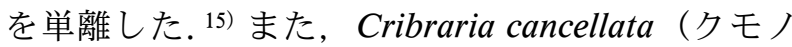
スホコリ) からも新ナフトキノン cribrarione B (11) を単離した. ${ }^{16)}$ Lindbladia tubulina（フンホコリ） からは主要赤色色素 lindbladione（12）とともに, 新規ナフトキノン型赤色色素 7-methoxylindbladione (13), 6,7-dimethoxylindbladione (14), dihydrolindbladione (15), 6-methoxydihydrolindbladione (16)，及び 6,7-dimethoxydihydrolindbladione (17) を単離した。 ${ }^{17,18)}$ Lindbladione（12） は Lindbladia

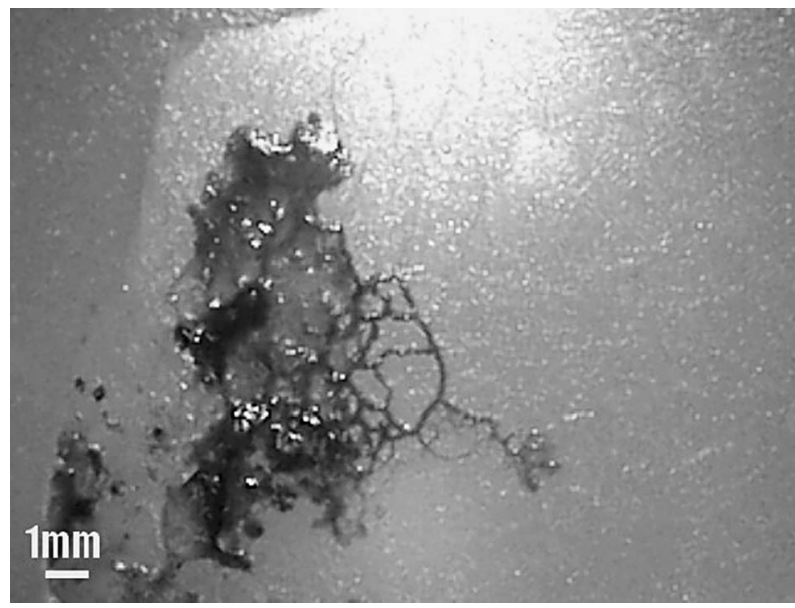

Fig. 9. Cultured Plasmodium (Didymium flexosum), Purple Color<smiles>CC(O)c1cc(O)c2c(c1O)C(=O)C(O)=CC2=O</smiles>

11<smiles>[R20]Oc1cc2c(c(O)c1[R20])C(=O)C(CCC(=O)CCC)=C(O)C2=O</smiles>

$$
\begin{array}{ll}
15 & R_{1}=R_{2}=H \\
16 & R_{1}=C_{3}, R_{2}=H \\
17 & R_{1}=R_{2}=C_{3}
\end{array}
$$

cribraioides (夕チフンホコリ), Cribraria intricata （フシアミホコリ）の主要赤色色素でもあることも 分かった. ${ }^{19)}$

3-2. ビスインドール上述のように, 野外採 取した一連の変形菌の子実体抽出物について HeLa 細胞に対する細胞周期阻害活性についてスクリーニ ング試験を行い，その結果に基づき，次の菌株を選 別し成分研究を行った。まず, Tubifera casparyi （オオクダホコリ）の子実体抽出物より 3 種の既知 ビスインドール型黄色色素 arcyriaflavin A-C (1820）を単離した。特に arcyriaflavin C（20）は 100 $\mathrm{ng} / \mathrm{ml}$ の濃度で $\mathrm{G} 2 / \mathrm{M}$ 期における細胞周期進行阻 害作用を示した. ${ }^{20)}$ 作用機構に関する情報を得るた め arcyriaflavin B（19）及びC（20）について癌研究 会癌化学療法センターにおける 39 種のヒト癌細胞 
Table 2. Results of Screening Study on Extracts of Wild Fruit-bodies of Myxomycetes

\begin{tabular}{|c|c|c|c|c|c|c|}
\hline 目 & 科 & 種 & $\begin{array}{c}\text { エキス量 } \\
(\mathrm{mg})\end{array}$ & $\begin{array}{l}\text { 抗菌 } \\
\text { 活性 }\end{array}$ & $\begin{array}{l}\text { 細胞周期 } \\
\text { 阻害活性 }\end{array}$ & TLC \\
\hline Ceratiomyxales & Ceratiomyxaceae & Ceratiomyxa fruticulosa & 6 & - & & \\
\hline \multirow{7}{*}{ Liceales } & \multirow{4}{*}{ Cribrariaceae } & Cribraria cancellata & 732 & + & - & Red pigment \\
\hline & & Cribraria intricata & 151 & - & - & Red pigment \\
\hline & & Cribraria purpurea & 120 & + & - & Red pigment \\
\hline & & Lindbladia cribrarioides & 850 & - & - & Red pigment \\
\hline & \multirow{3}{*}{ Enteridiaceae } & Lycogala epidendrum & 6850 & - & + & $\underset{\text { Ehrlich }(+)}{\text { Pigment, Fastred }(+),}$ \\
\hline & & Tubifera casparyi & 721 & - & + & Yellow pigment \\
\hline & & Tubifera dimorphotheca & 305 & - & - & - \\
\hline \multirow{4}{*}{ Trichiales } & \multirow{2}{*}{ Arcyriaceae } & Arcyria ferruginea & 78 & - & + & Red pigment \\
\hline & & Arcyria cinerea & 220 & - & & \\
\hline & \multirow{2}{*}{ Trichiaceae } & Metatrichia floriformis & 28 & + & + & - \\
\hline & & Hemitrichia clavata var. calyculata & 7 & - & & - \\
\hline \multirow{9}{*}{ Physarales } & \multirow{5}{*}{ Physaraceae } & Fuligo aurea & 80 & - & - & Yellow pigment \\
\hline & & Fuligo candida & 11750 & - & - & Fastred $(+)$, Ehrlich $(+)$ \\
\hline & & Craterium aureum & 11 & - & & \\
\hline & & Physarum bivalve & 4 & - & & \\
\hline & & Physarum bogorience & 21 & - & & - \\
\hline & \multirow{4}{*}{ Didymiaceae } & Diachea bulbillosa & 54 & + & & - \\
\hline & & Diderma spumarioides & 180 & - & - & - \\
\hline & & Didymium minus & 30 & - & & \\
\hline & & Didymium squamulosum & 22 & - & & \\
\hline \multirow{6}{*}{ Stemonitales } & \multirow{6}{*}{ Stemonitaceae } & Lamproderma sauteri & 752 & - & \pm & Dragendorf $(+)$ \\
\hline & & Stemonitis axifera & 272 & - & & \\
\hline & & Stemonitis axifera var. smithii & 45 & + & & \\
\hline & & Stemonitis fusca & 250 & - & & Ehrlich $(+)$ \\
\hline & & Stemonitis fusca var. rufescens & 174 & - & & \\
\hline & & Stemonitis splendens & 630 & - & & - \\
\hline
\end{tabular}

パネルスクリーニング試験に供した. ${ }^{21,22)}$ その結 果，特に arcyriaflavin C (20) については, 細胞株 選択性が十分高く，また類似する finger print パ ターンを持つ既知の抗癌剂も存在しなかつたため, 未知の作用機構を持つ可能性が示唆された。In vivo 試験検定の価值がある最も興味深い化合物で あるという評価（ネ印：“the most interesting”）を 得た。

一方, Arcyria ferruginea（トビゲウツボホコリ） からは既知の arcyriaflavin C（20） 及び arcyriaru- bin C（21）とともに，新規ビスインドール dihydroarcyriarubin C (22) を単離した. ${ }^{20)}$ 本化合物 の 8 位， 8'位の立体化学については未決定であつた ため, マレイミドと $2 つ$ のンドールをカップリン グさせる方法により，2つのジアステレオマー [ト ランス体（22）及びシス体（23）］を各々全合成し, スペクトルデータの比較により，天然物はトランス 配置（22）であると決定した. ${ }^{23)}$

また，比較的多く採取された Lycogala epidendrum（マメホコリ）の子実体抽出物からは, 
lycogarubin B (24), staurosporinone（25）を始めと する多くの既知ビスインドールアルカロイドととも に, ${ }^{21)}$ 新規化合物として 6-hydroxystaurosporinone （26）及び 5,6-dihydroxyarcyriaflavin A（27）を単 離した。これらは，顕著な細胞毒性を示したほか， 特に，26については，プロテインチロシンキナー ゼ（PTK）阻害活性を有することが明らかとなつ た. ${ }^{24)}$
これらのほかに, Arcyria cinerea（シロウツボホ コリ）の子実体抽出物からは，2 種の新規ビスイン ドール化合物 cinereapyrrole A（28）及び B (29)

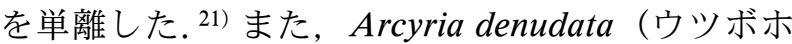
コリ）からは，新規ビスインドール硫酸エステル （30）及び arcyroxocin B（31）を，arcyriarubin C (21) 等の既知ビスインドールとともに単離した. さらに, Arcyria obvelata (キウツボホコリ)より， dihydroarcyriacianin A (32) を arcyriaflavin B (19) とともに単離した。Arcyroxocin B (31) と dihydroarcyriacianin A (32) は SciFinder 検索ではヒ ットしなかったが，化学構造式のみが学会要旨に記 載されていた. ${ }^{1)} \mathrm{NMR}$ データ等の詳細な実験デー 夕については，われわれの報告が初めてであつ た. ${ }^{25)}$

当研究室において, 最近, シグナル伝達分子 （Wnt，ヘッジホッグ，及びデスレセプター関連シ グナル等）を標的とした低分子化合物のスクリーニ<smiles>O=C1NC(=O)C(c2c[nH]c3cc(O)ccc23)=C1c1c[nH]c2cc(O)ccc12</smiles>

21<smiles>O=C1NC(=O)[C@@H](c2c[nH]c3cc(O)ccc23)[C@H]1c1c[nH]c2cc(O)ccc12</smiles>

22<smiles>CC(=O)c1[nH]c(C(C)=O)c(-c2c[nH]c3ccc(O)cc23)c1-c1c[nH]c2ccccc12</smiles>

24<smiles>O=C1NCc2c1c1c3ccccc3[nH]c1c1[nH]c3cc(O)ccc3c21</smiles><smiles>O=C1NC(=O)[C@H](c2c[nH]c3cc(O)ccc23)[C@H]1c1c[nH]c2cc(O)ccc12</smiles>

23<smiles>O=C1NCC2=C1c1c([nH]c3ccccc13)Nc1ccccc12</smiles>

25<smiles>O=C1NC(=O)c2c1c1c3ccccc3[nH]c1c1[nH]c3cc(O)c(O)cc3c21</smiles>

27 


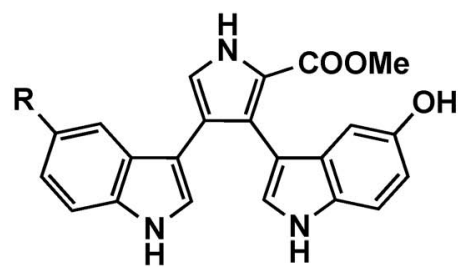

$28 \mathrm{R}=\mathrm{OH}$

$29 \mathrm{R}=\mathrm{H}$

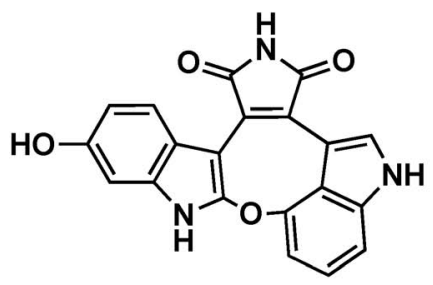

31<smiles>O=C1NC(=O)C(c2c[nH]c3ccccc23)=C1c1c[nH]c2ccccc12</smiles>

30

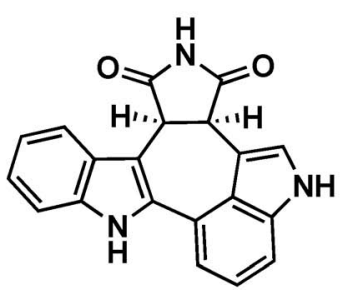

32
ングを行っているが，その過程で，これらビスイン ドール化合物が興味深い作用を示すことが分かって きた。すなわち， staurosporinone（25）及び arcyriaflavin C (20) は, ヘッジホッグシグナル伝達 系における GLI 転写阻害活性を持ち, ${ }^{26)}$ 一方, lycogarubin B（24）及び cis-dihydroarcyriarubin C （22）（非天然型合成品）は，Wnt シグナル伝達系 における $\beta$-catenin/TCF の転写阻害活性を示すこ とが明らかとなった. ${ }^{23,27)} 2$ 位-2'位間の炭素炭素結 合の有無がこのような活性の相違に関連しているか もしれない.

3-3. シクロアントラニリルプロリン（Fuligo candida の成分） Fuligo candida（シロススホコ リ）の野外子実体からは, cycloanthranilylproline (33)，及び関連する一連の新規化合物 fuligocandin A-C (34-36) を単離した. ${ }^{28)}$ 本菌からは, 同時に $p$-aminobenzoyltryptophan（37）も単離した。化合 物 33 及び fuligocandin A (34) はマウス白血病細 胞P388 に対して細胞毒性を示した.

一方, fuligocandin B (35) は TRAIL 耐性細胞 （成人 $\mathrm{T}$ 細胞白血病細胞株 $\mathrm{KOB}$ ）に対する耐性克 服作用を示した。すなわち fuligocandin B (35) $1.25 \mu \mathrm{g} / \mathrm{ml}$ 単独では, KOB 細胞に対して細胞増殖 阻害作用を示さなかつたが，fuligocandin B (35) $1.25 \mu \mathrm{g} / \mathrm{ml}$ と TRAIL $0.5 \mu \mathrm{g} / \mathrm{ml}$ とを併用すると 77 \%の細胞増殖阻害活性が認められた（TRAIL 0.5 $\mu \mathrm{g} / \mathrm{ml}$ 単独での細胞増殖阻害率は $12 \%)$ 。また，両
者の併用によりカスパーゼ 8, 9, 3 の経時的活性化 も認められた。しかし， Bcl2, XIAP などのアポ トーシス抑制因子や Bak, Bax などのアポトーシス 増強因子の発現には影響がなく, TRAIL デスレセ プターの増減も認められなかった。ただし, fuligocandin B (35) と TRAIL の併用によりミト コンドリア膜電位の経時的な低下が認められたこと から，両者の併用によるミトコンドリア系経路にお ける制御因子の変化が TRAIL 作用増強に係わつて いることが示唆された. ${ }^{29)}$

3-4. Fuligo aurea（ムシホコリ）の成分野 外採取した Fuligo aurea（ムシホコリ）の子実体か らは，cis- 及び trans-L-トリプトファン 4-アミノ桂

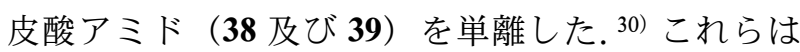
新規化合物であつたが，Fuligo candida 由来の化合 物 37 と関連した構造を有していた。同時に，F. aurea の脂溶性画分からは，六環性トリテルペンで ある chamaecydin (40) を単離した。興味深いこと に, この化合物 $\mathbf{4 0}$ は, 以前にヒノキ (Chamaecyparis obtuse $)^{31)}$ 又はスギ (Cryptomeria japonica) ${ }^{32)}$ の成 分として報告されていたものであった。 F. aurea は 通常, 広葉樹の腐木に多く発生する種類であり, 本 実験に用いた F. aurea のサンプルはすべてシイタ ケのホダ木に発生したもので，ヒノキ又はスギに発 生したものではなかった。Chamaecydin（40) は変 形菌自身が作ったのか，それとも植物由来の成分が 変形菌体内に蓄積されたのか，いずれであるか興味 


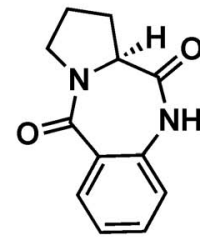

33

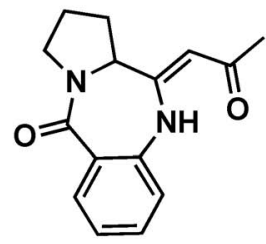

34<smiles>O=C(/C=C1\Nc2ccccc2C(=O)N2CCCC12)/C=C/c1c[nH]c2ccccc12</smiles>

35<smiles>O=C(O)CC(=O)C=C1Nc2ccccc2C(=O)N2CCCC12</smiles>

36<smiles>Nc1ccc(C(=O)NC(Cc2c[nH]c3ccccc23)C(=O)O)cc1</smiles>

37<smiles>Nc1ccc(/C=C\C(=O)N[C@@H](Cc2c[nH]c3ccccc23)C(=O)O)cc1</smiles><smiles>Nc1ccc(/C=C/C(=O)N[C@@H](Cc2c[nH]c3ccccc23)C(=O)O)cc1</smiles>

39

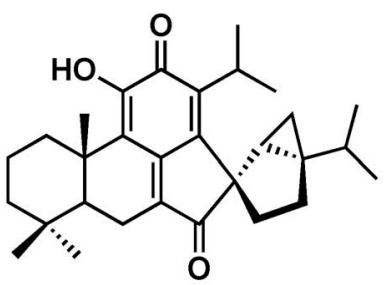

40

が持たれる.

3-5. テルペノイド（Tubifera dimorphotheca の 成分） Tubifera dimorphotheca（コモチクダホ コリ）の野外子実体から新規トリテルペンアルデヒ ドラクトン tubiferal A（41） 及びそのセコ酸 tubiferal B (42) を単離した. ${ }^{33)}$ tubiferal A (41) は 五, 六, 七員環の炭素環, $\gamma$-ラクトン環, アルデ ヒド，1,2- ジオールなどを含むユニークな構造を持 つが，その炭素骨格は，シクロアルタン骨格の三員 環が開裂した転位型骨格に相当する (Scheme 1).

また, tubiferal A (41) は, ビンクリスチン (VCR) 耐性 KB 細胞に対して, VCR 存在下, 細胞毒性を 示した $\left(\mathrm{IC}_{50}\right.$ 值 $\left.2.7 \mu \mathrm{g} / \mathrm{ml}\right)$ 。これは $\mathrm{VCR}$ 非存在下 時 $\left(\mathrm{IC}_{50}\right.$ 值 $\left.>12.5 \mu \mathrm{g} / \mathrm{ml}\right)$ のおよそ 4 倍以上の効果
であったため, 薬剤耐性克服作用が認められた.

3-6. Trichia favoginea var. persimilis（トゲケホ コリ）の成分野外採取した本菌の子実体より細 胞増殖抑制活性を持つ新規化合物としてジベンゾフ ラン成分 kehokorin A-C (43-45) ${ }^{34)}$ 及びユニークな 2,6- ジオキサビシクロ [2.2.2] オクタン -3- オン環 を含む新規ステロール trichiol A（46）及び B (47) ${ }^{35)}$ を単離した. Kehokorin A (43) は, Kehokorin B (44) をアグリコンとする L- ラムノース 配糖体である，Kehokorin A（43）は，糖を含まな い kehokorin B (44) 及び C (45) よりも強い細胞 増殖抑制作用（43-45 の HeLa 細胞に対する $\mathrm{IC}_{50}$ 值： $1.5,7.2$,及び $8.4 \mu \mathrm{g} / \mathrm{ml}$ ) を示した。また， trichiol A（46） 及び B (47) は同一変形菌から分離 


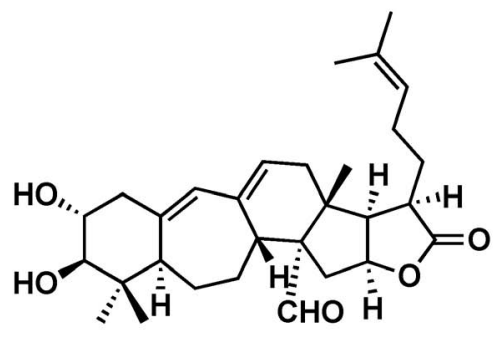

41

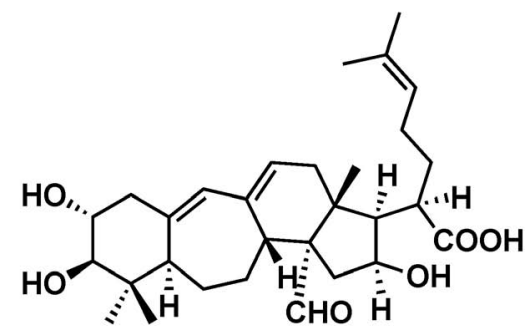

42

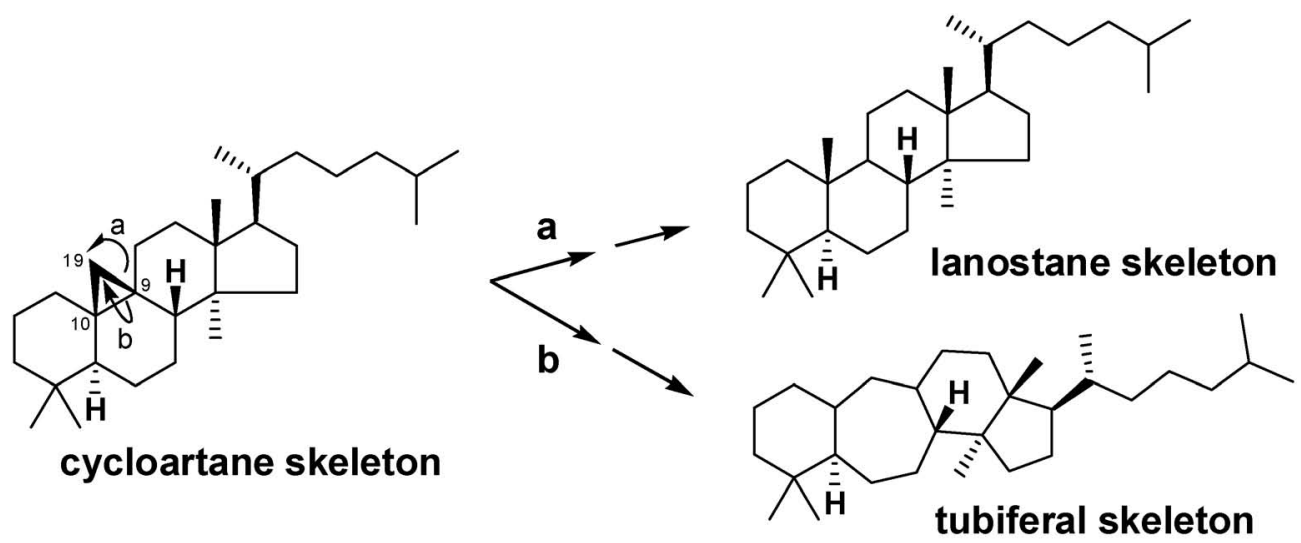

Scheme 1. Conceivable Backbone Rearrangements from the Cycloartane Skeleton

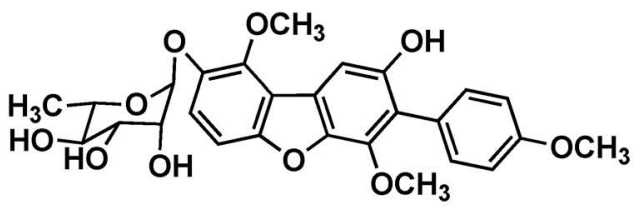

43

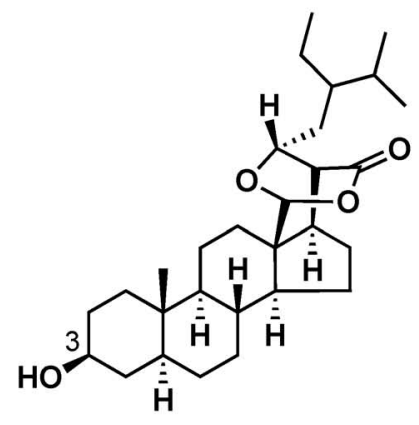

46<smiles>[R]c1c(O)ccc2oc3c(OC)c(-c4ccc(OC)cc4)c(O)cc3c12</smiles>

$44 \mathrm{R}=\mathrm{OCH}_{3}$

$45 \mathrm{R}=\mathrm{H}$
されたにも係わらず，3 位の立体配置は逆であつた.

一方，類縁の Trichia favoginea（ヒョウタンケホ コリ）の野外採取子実体からも，上記の成分と関連 した新規化合物 kehokorin D (48) 及び E (49)，並 びに, trichiol C $(\mathbf{5 0})$ 及び D (51) を単離した. ${ }^{36)}$

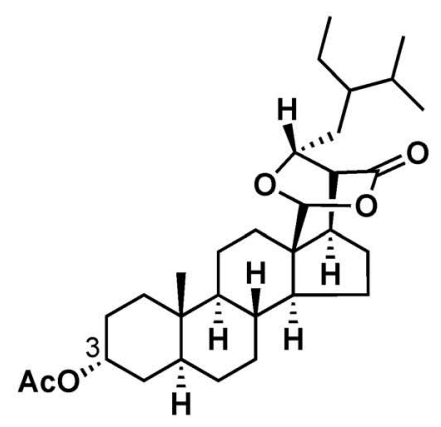

47

性構造化学研究室において行われたものであり, 研 究室メンバーの努力に深く感謝します。変形菌の採 取並びに同定では山本幸憲先生（高知市），松本 淳博士 (福井総合博物館), 及び日本変形菌研究会 の皆様にお世話になりました，また，培養に関する 実験では，杏林製薬・伊藤 明博士の丁寧なご指導 と励ましを賜りました。また，本研究の遂行に当た 


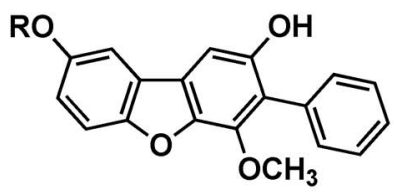

$48 \mathrm{R}=\mathrm{CH}_{3}$

$49 \mathrm{R}=\mathrm{H}$

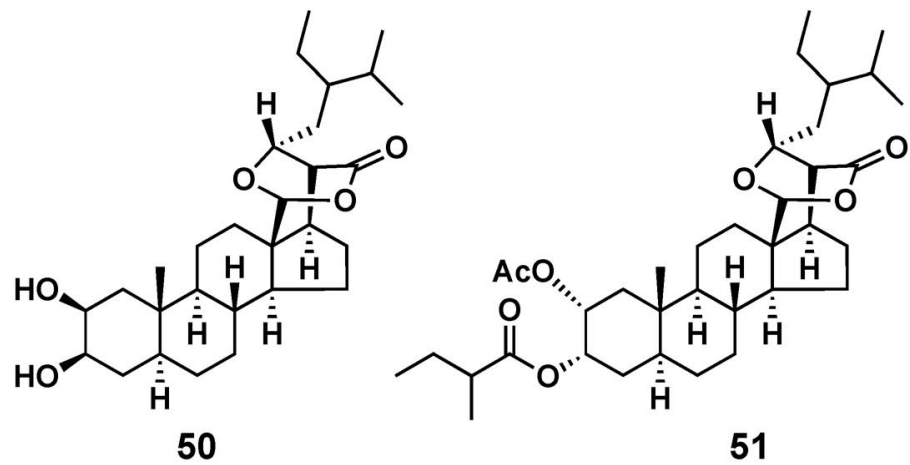

り御支援を賜りました科学研究費補助金特定領域研

究, 同基盤研究, 薬学研究奨励財団, 長瀬科学技術 振興財団，内藤記念科学振興財団，持田記念医学薬 学振興財団, 日本証券奨学財団, 上原記念生命科学 財団，医薬資源研究振興会，啓明会，テルモ科学技 術振興財団，及び千葉大学ベンチャービジネスラボ ラトリー(施設長裁量経費)に深く感謝いたします。

\section{REFERENCES}

1) Steglich W., Pure Appl. Chem., 61, 281-288 (1989).

2) Hashimoto T., Yasuda A., Akazawa K., Takaoka S., Tori M., Asakawa Y., Tetrahedron Lett., 35, 2559-2560 (1994).

3) Ishibashi M., Biosci. Ind., 63, 467-470 (2005).

4) Ishibashi M., Med. Chem., 1, 575-590 (2005).

5) Ishibashi M., Yuki Gosei Kagaku Kyokai-Shi, 61, 152-163 (2003).

6) Ishibashi M., "Studies in Natural Products Chemistry", Vol. 29, ed. by Atta-ur-Rahman, Elsevier Science, Amsterdam, 2003, pp. 223262.

7) Ishibashi M., Iwasaki T., Imai S., Sakamoto S., Yamaguchi K., Ito A., J. Nat. Prod., 64, 108-110 (2001).

8) Radisky D. C., Radisky E. S., Barrows L. R., Copp B. R., Kramer R. A., Ireland C. M., $J$. Am. Chem. Soc., 115, 1632-1638 (1993).

9) Misono Y., Ishibashi M., Ito A., Chem.
Pharm. Bull., 51, 612-613 (2003).

10) Nakatani S., Kiyota M., Matsumoto J., Ishibashi M., Biochem. Syst. Ecol., 33, 323325 (2005).

11) Schmidt E. W., Harper M. K., Faulkner D. J., J. Nat. Prod., 58, 1861-1867 (1995) .

12) Misono Y., Ito A., Matsumoto J., Sakamoto S., Yamaguchi K., Ishibashi M., Tetrahedron Lett., 44, 4479-4481 (2003).

13) Nakatani S., Kamata K., Sato M., Onuki H., Hirota H., Matsumoto J., Ishibashi M., Tetrahedron Lett., 46, 267-271 (2005) .

14) Hanazawa S., Kimura N., Arai M. A., Ishibashi M., Abstracts of Papers, the 127th Annual Meeting of the Pharmaceutical Society of Japan, Toyama, March 2007, No. 4, p. 6.

15) Naoe A., Ishibashi M., Yamamoto Y., Tetrahedron, 59, 3433-3435 (2003).

16) Iwata D., Ishibashi M., Yamamoto Y., J. Nat. Prod., 66, 1611-1612 (2003).

17) Ishikawa Y., Ishibashi M., Yamamoto Y., Hayashi M., Komiyama K., Chem. Pharm. Bull., 50, 1126-1127 (2002).

18) Misono Y., Ishikawa Y., Yamamoto Y., Hayashi M., Komiyama K., Ishibashi M., $J$. Nat. Prod., 66, 999-1001 (2003).

19) Misono Y., Nakatani S., Kamata K., Ishibashi M., Abstracts of Papers, the 50th Annual Meeting of the Japanese Society of Pharmacognosy, Tokyo, September 2003, p. 68.

20) Nakatani S., Naoe A., Yamamoto Y., Yamau- 
chi T., Yamaguchi N., Ishibashi M., Bioorg. Med. Chem. Lett., 13, 2879-2881 (2003).

21) Kamata K., Kiyota M., Naoe A., Nakatani S., Yamamoto Y., Hayashi M., Komiyama K., Yamori T., Ishibashi M., Chem. Pharm. Bull., 53, 594-597 (2005).

22) Kamata K., Suetsugu T., Kato Y., Hosoya T., Sonoda T., Ohtsuki T., Ishibashi M., Abstracts of Papers, the 15th Symposium on the Development and Application of Naturally Occurring Drug Materials, Tokyo, November 2005, pp. 258-261.

23) Kaniwa K., Arai M. A., Li X., Ishibashi M., Bioorg. Med. Chem. Lett. 17, 4254-4257 (2007).

24) Hosoya T., Yamamoto Y., Uehara Y., Hayashi M., Komiyama K., Ishibashi M., Bioorg. Med. Chem. Lett., 15, 2776-2780 (2005).

25) Kamata K., Suetsugu T., Yamamoto Y., Hayashi M., Komiyama K., Ishibashi M., J. Nat. Prod., 69, 1252-1254 (2006) .

26) Hosoya T., Arai M. A., Ishibashi M., Abstracts of Papers, the 127th Annual Meeting of the Pharmaceutical Society of Japan, Toyama, March 2007, No. 4, p. 126.

27) Li X., Ohtsuki T., Ishibashi M., Abstracts of Papers, the 127th Annual Meeting of the Pharmaceutical Society of Japan, Toyama, March
2007, No. 4, p. 126.

28) Nakatani S., Yamamoto Y., Hayashi M., Komiyama K., Ishibashi M., Chem. Pharm. Bull., 52, 368-370 (2004).

29) Hasegawa H., Komiyama K., Isihibashi M., Hayashi M., Sunazuka T., Abstracts of Papers, the 10th Annual Meeting of Japanese Association for Molecular Target Therapy of Cancer, Tokyo, June 2006, p. 100.

30) Hosoya T., Kato Y., Yamamoto Y., Hayashi M., Komiyama K., Ishibashi M., Heterocycles, 69, 463-468 (2006).

31) Hirose Y., Hasegawa S., Ozaki N., Tetrahedron Lett., 24, 1535-1538 (1983).

32) Shibuya T., Phytochemisty, 12, 4289-4294 (1992).

33) Kamata K., Onuki H., Hirota H., Yamamoto Y., Hayashi M., Komiyama K., Sato M., Ishibashi M., Tetrahedron, 60, 9835-9839 (2004).

34) Kaniwa K., Ohtsuki T., Yamamoto Y., Ishibashi M., Tetrahedron Lett., 47, 15051508 (2006).

35) Kaniwa K., Ohtsuki T., Sonoda T., Yamamoto Y., Hayashi M., Komiyama K., Ishibashi M., Tetrahedron Lett., 47, 4351-4354 (2006).

36) Watanabe K., Ohtsuki T., Yamamoto Y., Ishibashi M., Heterocycles 71, 1807-1814 (2007). 